\title{
Endocrine abnormalities and myopathy in Bloom's syndrome
}

\author{
U. AHMAD, E. R. FISHER, T. S. DANOWSKI, S. NOLAN, AND T. STEPHAN \\ From the Departments of Medicine and Pathology, Shadyside Hospital, and the University of Pittsburgh \\ School of Medicine, Pittsburgh, Pennsylvania, USA
}

SUMMARY Abnormal endocrine indices and myopathy have been variably present in two brothers with Bloom's syndrome (congenital teleangiectatic erythema, hypersensitivity to light, and growth? retardation). These consisted of : (1) growth retardation with height and weight below the third centiles;; $\overrightarrow{+}$ in the younger one at age 14, hypoglycaemia failed to elicit a rise in growth hormone but did so in the older one at age $17 ;(2)$ serum TSH was raised in the older one in whom serum FSH and LH were also $\vec{\infty}$ above the normal range; and (3) myopathy characterised by pronounced dilatation of the sarcoplas-은 mic reticulum was present in the younger one; distinct reduction of muscle strength was shown in hisolder brother with ultrastructural alteration of skeletal muscle of unknown significance.

Bloom's syndrome (Bloom, 1954a, b; Szalay, 1963; Bloom, 1966; Sawitsky et al., 1966; Schoen and Shearn, 1967; German, 1969, 1972, 1974) is an autosomal recessive inheritable disorder characterised by teleangiectasia, hypersensitivity to sunlight, growth retardation in utero and thereafter, and chromosomal aberrations with quadriradial (Qr) forms. More than one-half of cases have appeared in Ashkenazik Jews as well as in offspring of consanguineous unions (Bloom, 1954a; German, 1974). Other congenital anomalies of the ears, teeth, and extremities have been observed as well as an increased propensity of these individuals to develop neoplastic disease. Weakened, delayed, or absent hypersensitivity responses, hypogammaglobulinaemia, as well as frequent respiratory and gastrointestinal infections have been noted (German, 1974). Though occasional cryptorchidism (cases 3, 4, and $\mathrm{HC}$ in Bloom, 1954a) and one instance of aspermia (German, 1974) have been encountered, no other endocrinopathy, except possibly the stunting, has been observed.

This report concerning two brothers with this entity who earlier had been reported as cases 3 and 4 in Bloom's series (1954a) discloses the absence of a growth hormone response to hypoglycaemia in one and high serum thyroid stimulating hormone (TSH) and increased levels of serum follicle stimulating and luteinising hormones (FSH and LH) in the other.

Received for publication 3 May 1977
These findings suggest that endocrinopathy may develop with increasing age in these patients. addition, muscle weakness was present in one of the two brothers, with pronounced dilatation of the sarcoplasmic reticulum in the other.

\section{Clinical findings}

The history of these two brothers at the age of 4 years $\overrightarrow{\vec{A}}$ and 7 years, respectively, has been previously 3 reported by Bloom (1954a). Subsequent to that? publication, the younger patient (LS), now age 160 years, has failed to grow at a normal rate and has been found to have an IQ of less than 90 . He experi-ô้ enced frequent respiratory infections including two episodes of pneumonia and has taken prophylactic antibiotics for infections.

The older brother (CS), now age 18 years and 113 months, also failed to grow normally and has a 'dull-o normal' IQ. He failed three school grades. He also had respiratory infections, though less frequent ando less severe than those of his brother. He suffered from severe photophobia.

Physical examination showed that both were belown the third centile for height and weight. Both hadN facial telangiectasia and desquamation, moderate inthe younger and more severe involving all of the faces in the older one. The lips were dry and desquamating in each. Partial syndactyly was present in the secondes and third toes of both feet in the two patients. The 
testes measured $2.5 \mathrm{~cm}$ in length in both patients and the penis was commensurate with body size. Pubic hair was present only in the older brother who also had clubbing of the fingers.

\section{Laboratory findings}

Blood and serum solutes, including liver indices and lipids, were within the normal range in both patients. Oral glucose tolerance test was normal. Thus, ingestion of $1.75 \mathrm{~g}$ glucose per $\mathrm{kg}$ body weight yielded a normal glucose tolerance sum $\left(\mathrm{GTS}_{0-2 \mathrm{hr}}\right.$-sum of the blood glucose values at $0, \frac{1}{2}, 1$, and 2 hours) of 406 (Danowski et al., 1970). In the older sib, the GTS $_{0-2}$ hr value was also normal at 416 . This was also true of creatinine clearance and urinary 17-ketosteroids, Porter-Silber chromogens, and 11-desoxycortisol metabolites.

Skull and chest $x$-rays were negative. Bone age in the younger brother was three years below the chronological age; in the older, bone age was one year above the chronological age. Electrocardiogram tracings were normal and urine analyses were negative. In the younger boy, $7 \%$ eosinophilia was noted in the peripheral blood smear. The remainder of the peripheral blood count was normal in both.

Endocrine findings, with one exception, were normal in the younger of the two brothers. In the younger brother, the fasting growth hormone levels were less

Table 1 Intravenous insulin $(0 \cdot 1$ unit $/ k g$ body weight $)$ tolerance tests

\begin{tabular}{|c|c|c|c|c|c|c|}
\hline \multirow[t]{2}{*}{ Patient } & \multirow[t]{2}{*}{ Index } & \multicolumn{5}{|l|}{ Time } \\
\hline & & 0 & $15^{\prime}$ & $30^{\prime}$ & $60^{\prime}$ & $120^{\prime}$ \\
\hline \multirow[t]{2}{*}{ LS } & $\begin{array}{l}\text { Blood glucose (mg/100 } \\
\text { ml) }\end{array}$ & 74 & 30 & 56 & 58 & 70 \\
\hline & $\begin{array}{l}\text { Serum insulin (uU/ml) } \\
\text { Serum growth hormone } \\
\quad(\mathrm{ng} / \mathrm{ml})\end{array}$ & $\begin{array}{l}<1 \\
<1 \cdot 0\end{array}$ & $\begin{array}{l}398 \\
<2 \cdot 5\end{array}$ & $\begin{array}{l}42 \\
<2 \cdot 5\end{array}$ & $\begin{array}{l}<3 \\
<2.5\end{array}$ & $\begin{array}{l}<3 \\
<2.5\end{array}$ \\
\hline \multirow[t]{2}{*}{ CS } & $\begin{array}{l}\text { Blood glucose }(\mathrm{mg} / 100 \\
\mathrm{ml})\end{array}$ & 74 & 30 & 47 & 45 & 76 \\
\hline & $\begin{array}{l}\text { Serum insulin (uU/ml) } \\
\text { Serum growth hormone } \\
\quad(\mathrm{ng} / \mathrm{ml})\end{array}$ & $\begin{array}{l}38 \\
<1 \cdot 0\end{array}$ & $\begin{array}{l}34 \\
<2 \cdot 5\end{array}$ & $\begin{array}{l}87 \\
31 \cdot 2\end{array}$ & $\begin{array}{l}21 \\
39 \cdot 2\end{array}$ & $\begin{array}{l}12 \\
48 \cdot 5\end{array}$ \\
\hline
\end{tabular}

than $1 \mathrm{ng} / \mathrm{ml}$ at age 13 and did not increase during insulin-induced hypoglycaemia (Table 1). One year later, the fasting growth hormone level was $4.0 \mathrm{ng} / \mathrm{ml}$. Plasma cortisol was $10 \gamma \%$ in the morning and 5 in the afternoon. This younger patient responded to intravenous leutinising releasing hormone (LRH) with a rise in serum FSH from 9 to $18 \mathrm{mIU} / \mathrm{ml}$ in 3 hours with corresponding $\mathrm{LH}$ values of 5 and 50 $\mathrm{mIU} / \mathrm{ml}$ (Table 2). The basal testosterone level was $195 \mathrm{ng} / 100 \mathrm{ml}$. He also responded to intravenous thyroid-releasing hormone (TRH), with a rise in serum TSH from 10 to a peak of $32 \mu \mathrm{IU} / \mathrm{ml}$ at 30 minutes; and within the same period, prolactin increased from 7 to $12 \mathrm{ng} / \mathrm{ml}$. In addition, 3 hours after the TRH, serum triiodothyronine measured by radioimmunoassay (RIA- $\mathrm{T}_{3}$ ) had increased from 150 to $220 \mathrm{ng} / 100 \mathrm{ml}$.

The older sib responded adequately to insulininduced hypoglycaemia, that is the growth hormone rose from $1 \mathrm{ng} / \mathrm{ml}$ to $48 \mathrm{ng} / \mathrm{ml}$ at 30 minutes. He had increases in basal serum TSH to more than 100 $\mu \mathrm{IU} / \mathrm{ml}$ (normal range 2 to 10 ) and normal RIA-T $\mathrm{T}_{3}$ of $160 \mathrm{ng} / 100 \mathrm{ml}$ and RIA-T 4 of $7 \gamma \%$. In addition, his serum FSH was increased at 26 and at $22 \mathrm{mIU} / \mathrm{ml}$ when measured 4 weeks apart with corresponding LH values of 25 and $36 \mathrm{mIU} / \mathrm{ml}$. Serum testosterone was 420 and $658 \mathrm{ng} / 100 \mathrm{ml}$ at these times (normal 400 to 1000). Plasma cortisol was also normal at 20 $\gamma \%$ in the morning and 14 in the afternoon.

Chromosome analysis of short-term cultures of blood lymphocytes of each patient disclosed quadriradial (Qr) configuration of $\mathrm{E}$ group homologues indicative of multiple chromosome breakage and rearrangement of the type reported in Bloom's syndrome (Sawitsky et al., 1966; German, 1969, 1972, 1974; German et al., 1974; Schroeder and German, 1974; Hand and German, 1975).

Performance on recording ergometry (105 consecutive contractions of each hand at $1 \mathrm{~s}$ intervals) was normal in the younger patient but revealed a pronounced decline of excursions in the older one. Serum creatine kinase (CK) and aldolase were normal at 36 and 4 units, respectively, in the younger brother; but CK was raised to 123 units in the older brother. Motor nerve conduction velocity was normal in the median, ulnar, common peroneal, and posterior

Table 2 LRH (50 $\gamma N$ in 4 h), TRH (500 y bolus), and ACTH(cortrosyn, 0.75 mg bolus) in patient LS

\begin{tabular}{|c|c|c|c|c|c|c|c|}
\hline \multirow[t]{2}{*}{ Serum } & \multicolumn{7}{|l|}{ TIME } \\
\hline & 0 & $15^{\prime}$ & $30^{\prime}$ & $1^{\circ}$ & $2^{\circ}$ & $3^{\circ}$ & $4^{\circ}$ \\
\hline $\begin{array}{l}\text { Prolactin }(\mathrm{ng} / 100 \mathrm{ml}) \\
\text { TSH }(\mu \mathrm{IU} / \mathrm{ml}) \\
\text { RIA-T } \mathbf{3}(\mathrm{ng} / 100 \mathrm{ml}) \\
\text { FSH }(\mathrm{mIU} / \mathrm{ml}) \\
\mathrm{LH}(\mathrm{mIU} / \mathrm{ml})\end{array}$ & $\begin{array}{c}6 \cdot 8 \\
9 \cdot 7 \\
150 \\
8 \cdot 6 \\
5 \cdot 4\end{array}$ & $\begin{array}{r}12 \cdot 4 \\
32 \cdot 5 \\
\\
>5 \cdot 7\end{array}$ & $\begin{array}{c}28.5 \\
14.9 \\
>50\end{array}$ & $\begin{array}{r}5 \cdot 6 \\
18 \cdot 0 \\
\\
>5 \cdot 8\end{array}$ & $\begin{aligned} 4 \cdot 5 \\
9 \cdot 5 \\
13 \cdot 0 \\
>50\end{aligned}$ & $\begin{aligned} 7 \cdot 0 \\
5 \cdot 5 \\
18 \cdot 0 \\
>50\end{aligned}$ & $\begin{array}{c}2 \cdot 5 \\
5 \cdot 0 \\
220 \\
18 \cdot 4 \\
>50\end{array}$ \\
\hline
\end{tabular}




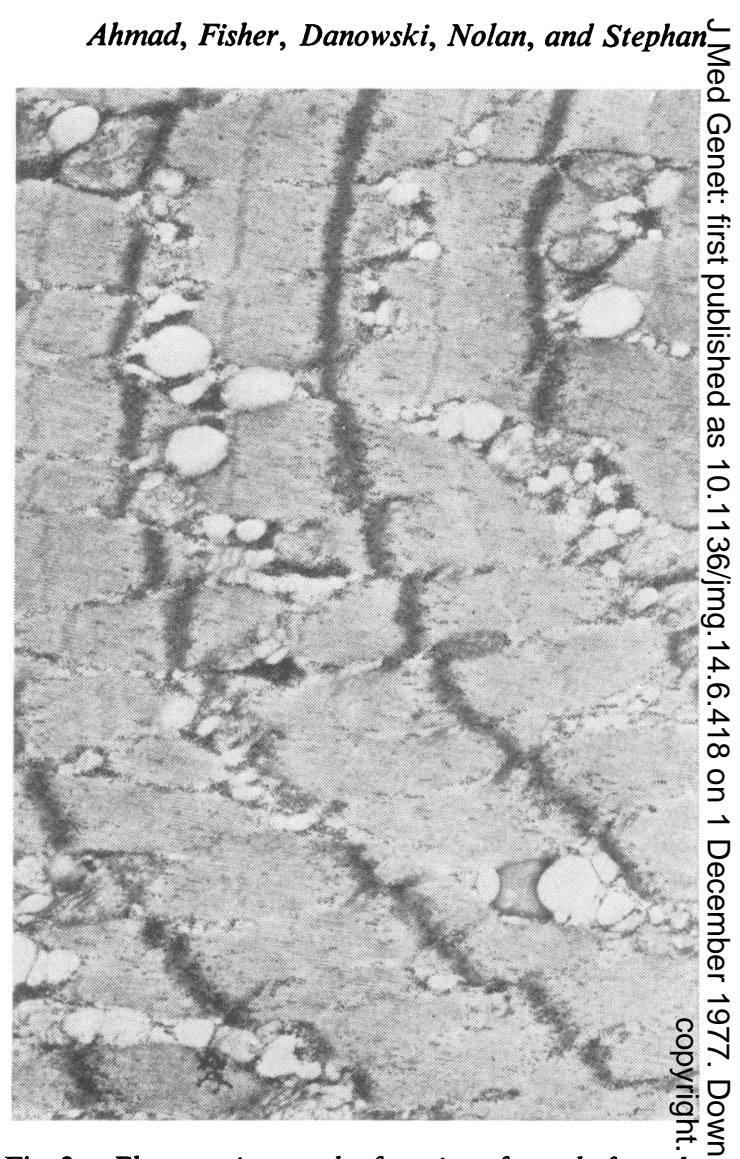

Fig. 2. Electronmicrograph of portion of muscle from the younger brother. There is pronounced dilatation of the sarcoplasmic reticulum like that observed in periodic $\stackrel{\mathbb{Q}}{\mathbb{2}}$ paralysis (× 11900$)$.

each year. First, Bloom's syndrome shows a simple recessive transmission which indicates that a single gene, $b l$, and a single enzyme is affected. The major manifestation of the gene $b l$, when homozygous, is growth retardation.

A second feature of interest is excessive chromosome instability ('breakage'). This suggests that the affected enzyme exerts its effect, directly or indirectly, on the genetic material itself, in this case, the chromo-o somes.

In addition, persons with Bloom's syndrome are ato a greatly increased risk with respect to leukaemia and gastrointestinal and other cancers. As yet there is noo evidence of neoplastic disease in the patients reported N herein.

Finally, previous reports and our data establish ${ }_{\sigma}^{\omega}$ that variable endocrinopathy can be a feature of Bloom's syndrome.

At first the absence of endocrine stigmata in the early published reports of Bloom's syndrome, the
German (1974) has pointed out several reasons why study of Bloom's syndrome is desirable even though only two or three affected persons are recognised

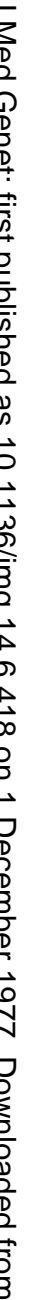


generally normal or only slightly retarded bone age, and the normal glucose tolerance, urinary 17-ketosteroids, and gonadotropins appeared to exclude endocrinopathy (Bloom, 1954a) other than that possibly responsible for the growth retardation. Furthermore, necropsy in one patient showed normal parathyroids, ovaries, and adrenals (Bloom, 1954a; Sawitsky et al., 1966). Moreover, recently German has reported that in women menarche and menses have been unremarkable (German, 1974). However, none of the three married men in his prospective study of Bloom's syndrome has had children, and evaluation of one revealed aspermia. He also reported that the testes of the adults in his series appeared to be 'disproportionately small'.

Findings in the older of the two patients whom we have restudied indicate that he had hypergonadotropic hypogonadism with high serum FSH and LH and that this was accompanied by increased levels of circulating TSH. These findings suggest gonadal and thyroidal failure but could reflect, alternatively, disturbances of the hypothalamus and/or pituitary. In the younger brother, both the gonadotropins and TSH levels were normal, but hypoglycaemia failed to evoke a rise in growth hormone. It is possible of course that hypoglycaemia was not an adequate stimulus in this patient. None the less, these findings suggest that in this entity, endocrinopathy such as growth hormone unresponsiveness present at an earlier age subsequently disappears. On the other hand, abnormalities of other endocrine indices such as increases in FSH, LH, and TSH may develop with increasing age.

The muscle biopsy of the older brother indicated abnormalities of the mitochondria and myofibres (Fisher and Danowski, 1974). The alterations observed in the biopsy from the younger brother, notably dilatation of sarcoplasmic reticulum, has not been encountered in control specimens and is a valid pathological change. Indeed, the appearance of the muscle is indistinguishable from that observed in familial periodic paralysis (Danowski et al., 1975). Muscle weakness and the associated myopathy have not been cited in previous reports of Bloom's syndrome.

\section{References}

Bloom, D. (1954a). Congenital telangiectatic erythema resembling lupus erythematosus in dwarfs; probably syndrome entity. American Journal of Diseases of Children, 88, 754-758.
Bloom, D. (1954b). Congenital telangiectatic erythema in a Levi-Lorain dwarf. Archives of Dermatology and Syphilology, 69, 526.

Bloom, D. (1966). The syndrome of congenital telangiectatic erythema and stunted growth. Journal of Pediatrics, 68, 103-113.

Danowski, T. S., Aarons, J. H., Hydovitz, J. D., and Wingert, J. P. (1970). Utility of equivocal glucose tolerances. Diabetes, 19, 524-526.

Danowski, T. S., Fisher, E. R., Vidalon, C., Vester, J. W. Thompson, R., Nolan, S., Stephan, T., and Sunder, J. H. (1975). Clinical and ultrastructural observations in a kindred with normo-hyperkalemic periodic paralysis. Journal of Medical Genetics, 12, 20-28.

Fisher, E. R., and Danowski, T. S. (1974). Electron microscopy in the study of disorders of skeletal muscle. In Pathology Annual, pp. 345-384. Ed. by S. C. Sommers. Appleton-Century-Crofts, New York.

German, J. (1969). Bloom's syndrome. I. Genetical and clinical observations in the first twenty-seven patients. American Journal of Human Genetics, 21, 196-227.

German, J. (1972). Genes which increase chromosomal instability in somatic cells and predispose to cancer. In Progress in Medical Genetics, 8, pp. 61-101. Ed. by A. G. Steinberg and A. G. Bearn. Grune and Stratton, New York and London.

German, J. (1974). Bloom's syndrome. II. The prototype of human genetic disorders predisposing to chromosome instability and cancer. In Chromosomes and Cancer, pp. 601-617. Ed. by J. German. John Wiley, New York.

German, J., Crippa, L. P., and Bloom, D. (1974). Bloom's syndrome. III. Analysis of the chromosome aberration characteristic of this disorder. Chromosoma, 48, 361-366.

Hand, R., and German, J. (1975). A retarded rate of DNA chain growth in Bloom's syndrome. Proceedings of the National Academy of Sciences of the United States of America, 73, 758-762.

Sawitsky, A., Bloom, D., and German, J. L. (1966). Chromosomal breakage and acute leukemia in congenital telangiectatic erythema and stunted growth. Annals of Internal Medicine, 65, 487-495.

Schoen, E. J., and Shearn, M. A. (1967). Immunoglobulin deficiency in Bloom's syndrome. American Journal of Diseases of Children, 113, 594-596.

Schroeder, T. M., and German, J. (1974). Bloom's syndrome and Fanconi's anemia: demonstration of two distinctive patterns of chromosome disruption and rearrangement. Humangenetik, 25, 299-206.

Szalay, G. C. (1963). Dwarfism with skin manifestations. Journal of Pediatrics, 62, 686-695.

Requests for reprints to Professor T. S. Danowski, Department of Medicine, Shadyside Hospital, 5230 Centre Avenue, Pittsburgh, Pennsylvania 15232, USA. 